Egyptian Poultry Science Journal

http://www.epsaegypt.com

ISSN: 1110-5623 (Print) - 2090-0570 (On line)

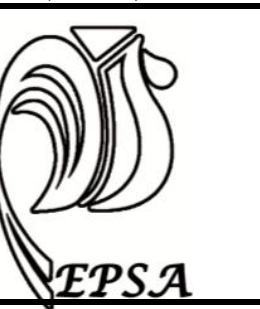

\title{
EFFECTS OF VITAMINS SUPPLEMENTATIONS ON PRODUCTIVE AND PHYSIOLOGICAL PERFORMANCE OF BROILERS UNDER WATER SALINITY STRESS
}

\section{Z. S. H. Ismail ${ }^{1}$; and H. A. M. Elwan²}

${ }^{1}$ Anim. and Poult. Prod. Dep., Fac. of Agric., South Valley Univ., Egypt

${ }^{2}$ Anim. and Poult. Prod. Dep., Fac. of Agric. Minia University, Egypt

Corresponding author: Zienhom Shikhown Hassan Ismail; E-mail: zien7300@yahoo.com

$$
\text { Received: 20/07/2016 Accepted: 17/08/2016 }
$$

\begin{abstract}
The current experiment was conducted to determine the effect of vitamins $\mathrm{E}$ and/or C during salinity stress of broiler chicks. One hundred and twenty-one day old unsexed broiler chicks were used in the experiment. Chicks were divided into four groups of 30 birds each with 10 birds per replicate. Treatments were drinking tap water (control group), $3000 \mathrm{ppm} \mathrm{NaCl}$ in drinking water (T1, $3000 \mathrm{ppm}$ salt stress group), $3000 \mathrm{ppm} \mathrm{NaCl}$ plus $100 \mathrm{IU} / \mathrm{kg}$ of feed DL- $\alpha$-tocopherol (T2, $3000 \mathrm{ppm} \mathrm{VE)} \mathrm{and} 3000 \mathrm{ppm} \mathrm{NaCl}$ plus 500 IU/L of water L-ascorbic acid (T3, $3000 \mathrm{ppm} \mathrm{VC).} \mathrm{Feed} \mathrm{and} \mathrm{water} \mathrm{intake,} \mathrm{live} \mathrm{body}$ weights were weekly recorded; weight gain and feed conversion ratio (FCR) were calculated. The experiment was lasted for 6 weeks. Six birds from each treatment were randomly selected and weighed for determining carcass dressing percentage. The results of the present studies indicated that, productive performance not adversely affected by $\mathrm{NaCl}$ supplementation in drinking water. Furthermore, adding Vita $\mathrm{E}$ or $\mathrm{C}$ improved BW and BWG compared with T1, Birds in T1 had the lowest WI. Contrary, birds in T3 had the highest WI compared with other groups. There was no significant difference between T2 and T3 in water intake. Birds in T4 group had the best FC comparing with other groups. Additionally, there were a significant decrease $(\mathrm{p}<0.01)$ in $\mathrm{Ca}$ concentration of birds received Vita $\mathrm{E}$ or $\mathrm{C}$ compared to other treatments. These results indicate that productive and physiological performance of broiler chicks was not adversely affected by 3000 ppm $\mathrm{NaCl}$ in drinking water supplemented with vita $\mathrm{C}$ and /or vita $\mathrm{E}$.
\end{abstract}

Key Words: Salinity Stress - Broiler - L-Ascorbic Acid - DL- A-Tocopherol - Carcass 


\section{INTRODUCTION}

Water makes up a large proportion of the body of the chicken, from $55 \%$ to $75 \%$, therefore it is essential for life. Chickens are able to survive much longer without feed than without water (Talha et al., 2008). A rule of thumb for water is that the bird consumes from 1.5 to 2 times as much water as it does feed (Kellems and Church, 2002). Therefore it is expected that any shortage in water contents will affect broiler performance more than its occurrence in feed contents. About $70 \%$ of body water is inside the cell and $30 \%$ in fluid surrounding the cell and in blood. As fat increases in the carcass with age, the percentage of total body water decreases. The bird obtains water by drinking, eating and catabolism of fatty deposits and other body tissues. Water acts as a solvent for other inorganic and organic nutrients, is essential in metabolism and required for movement of feed through the digestive system; water is able to store a large amount of heat in liquid form and then lose heat upon evaporation. Water quality, as related to poultry production, must consider temperature, dissolved minerals, organic material, and microbial contamination.

The poultry farm must be managed to provide clean and cool water to all birds at all time (Lesson and Summers, 1997), while the nutritional importance of minerals in the diets has been examined extensively, the role of minerals in drinking water received much less attention this is surprising since underground water supplies are a common source of drinking water for poultry in many countries and such water often contains high concentration of dissolved mineral salts.

Excess minerals in feed or water above the nutritional requirement will cause increased water consumption and may result in wet manure. Afifi et al. (1992) noted that the main cause of high mortality is the toxic effect of $\mathrm{NaCl}$ when used at high levels in feeds or water. The authors noted also that broiler chicks could tolerate up to $2 \mathrm{~g} \mathrm{NaCl}$ $/ 100 \mathrm{ml}$ in the drinking water, and live weight gains are decreased, water consumption and water to feed ratio are increased, and feed conversion ratio ( $\mathrm{g}$ feed/ $g$ gain) is adversely affected. Zimmermann et al. (1993) concluded that the inclusion of $\mathrm{NaCl}$ in broiler diet from $0.2-0.8 \%$ had no detrimental symptoms. And it demonstrated that broiler under the tropic can tolerate dietary salt up to $0.8 \%$ with advantageous result (improved carcass quality via decreased water holding capacity). Controlling salt in water is more important than in feed. Levels of $0.4 \%$ $0.9 \%-1.2 \%$ and $2.0 \%$ salt in drinking water have shown harmful effects with poultry. Water availability is essential to achieve efficient broiler production. However, there are many factors that may influence water intake by the birds, such as the intake of feed and minerals (Leeson and Summers, 1997). In 2005, Watkins et al., reported that the level of $\mathrm{Na}$ and $\mathrm{Cl}$ in drinking water and in the diet significantly affected live performance in broiler, with significant interaction between dietary and water levels. Water source of $\mathrm{NaCl}$ can be used to provide part or all of chicks need for these minerals, and adjustments in dietary levels of $\mathrm{Na}$ and $\mathrm{Cl}$ should be made, based on levels of these minerals in the drinking water. This should aid in reducing litter moisture for situations in which water supplies are high in saline water. It is estimated that $100 \mathrm{mg} \mathrm{Na} / \mathrm{L}$ in the water can replace approximately $0.05 \% \mathrm{Na}$ in the diet.

The amount of water intake is important, as it has a direct influence on feed intake (Soares et al., 2007; and Viola et al., 2009). Vitamin $\mathrm{E}$ has been reported as an excellent biological chain-breaking antioxidant that protects cells and tissue from lipoperoxidative damage induced by free 
radicals. Vitamin $\mathrm{C}$ limits the metabolic signs of stress and alleviates the physiological consequences of stress, resulting in improved performance, immunological competence and behavior of chickens. The antioxidative property of vitamin $E$ in chickens is suggested to have significant role in the development of immune response through protection of the cells, such as lymphocytes, macrophages, and plasma cells from oxidative damages, and enhances the function and proliferation of these cells in face the oxidative stress (Franchini et al., 1991; and Meydani and Blumberg, 1993).

Damron (1998) added up to $800 \mathrm{ppm} \mathrm{NaCl}$ to the drinking water of White Leghorn hens and detected that daily feed and water intake and body weight change over the experimental period were not influenced by any level of waterborne $\mathrm{NaCl}$. Khalafalla et al. (1998) reported that the toxicity of sodium chloride given in the drinking water was approximately the same as an equivalent intake from the diet. These authors also noted that a supplement of $3 \mathrm{~g}$ $\mathrm{NaCl} / \mathrm{l}$ to the drinking water was not toxic to two-day old chicks. Therefore, relatively low concentrations of sodium chloride in drinking water may improve live weight gain in broilers, perhaps through a greater retention of water. The aim of the present study to find out whether supply of $\mathrm{NaCl}$ in the drinking water would prove to be efficient under field conditions, and which concentration of either Vita $\mathrm{E}$ or Vita C should be used.

\section{MATERIALS AND METHODS}

\section{Treatments and Chicks Managements:}

One hundred and twenty one day-old Ross broiler chickens were wing-banded, individually weighed, and randomly assigned to four experimental groups, (control and 3 treatments). Each group included three replicates, each of 10 chicks. Birds in the G1, which served as the control, were drinking tap water, birds in G2 were drinking tap water Add to 3000 ppm $\mathrm{NaCl}$ in (salt stress group). Birds in the G3 were drinking tap water added to $3000 \mathrm{ppm} \mathrm{NaCl}$ plus $100 \mathrm{IU} / \mathrm{kg}$ of feed DL- $\alpha$-tocopherol (3000 ppm VE), G4 drinking tap water add to $3000 \mathrm{ppm} \mathrm{NaCl}$ plus 500 IU/L of water L-ascorbic acid (T3, $3000 \mathrm{ppm}$ VC). The light intensity for all experimental birds was 15 Lux during the first three days and 5 Lux thereafter.

Chicks were housed and raised in two tierswire floor, batteries with cages having the dimensions (width: $97 \mathrm{~cm}$; length: $50 \mathrm{~cm}$; height: $45 \mathrm{~cm}$ ), located in a closed broiler house under controlled managerial and hygienic conditions. The interior temperature which started by about $32{ }^{\circ} \mathrm{C}$ during the first week, was reduced by about $2{ }^{\circ} \mathrm{C}$ every week to reach $24{ }^{\circ} \mathrm{C}$ at the fourth week of age and remained constant in the presence of a relative humidity ranging between $55-60 \%$ up to the end of the experiment. The temperature values and the relative humidity percentages were daily recorded by using a thermohygrograph and the temperature humidity indices-THI values were calculated allover the experimental period. The birds were fed on starter and grower diets from 1 to 21 and 22 to 42 days of age, respectively and the feed and water were available all the time.

Studied criteria: Birds per each replicate were weekly weighed on individual basis. The body weight gain BWG was calculated as the difference between final and the initial body weight. The average feed intake FI per each replicate was weekly calculated as the difference between the offered and remained amounts of feed. The mean feed conversion ratio FCR was weekly calculated by dividing total feed consumed by the total body weight gain of birds per each replicate. At the end of the experiment at 42 days of age, 18 fasted chicks (for 8 hours) per each group i.e. three around the average weight / each replicate were slaughtered. After complete bleeding, they were scalded and mechanically plucked. The edible organs (heart, liver, empty gizzard and spleen) as 
well as the abdominal fat were gently removed, weighed and calculated as percentages of carcass weight. The dressing percentage was calculated, by dividing the carcass and giblets weights by the preslaughter live body weight of birds. Also, the lengths of intestines and ceca were recorded. Representative blood samples were collected from 9 hens randomly chosen from each treatment (3 from each replicate) at the end of the experiment and centrifuged. Serum was collected and stored at $-20{ }^{\circ} \mathrm{C}$ for determination of potassium $(\mathrm{K})$, calcium $(\mathrm{Ca})$, magnesium $(\mathrm{Mg})$, sodium $(\mathrm{Na})$, phosphorus $(\mathrm{P})$ and Aldestrol.

\section{Statistical Analysis:}

Data were statistically analyzed by ANOVA, using the General Linear Model (GLM) procedure of SAS software (SAS institute, version 9.1, 2005). Duncan's multiple range test (Duncan, 1955) was used to detect the differences among means of different groups.

\section{RESULTS AND DISCUSSION}

Data reported in Table 2 shows that, salt stress supplemented with vita E (T2) increased broiler BW at 3 weeks of age comparing with other treated groups. Whereas, there were no significant differences among control, salt and salt supplemented with vita $\mathrm{C}$ at 6 weeks of age. Moreover, at six weeks of age birds received salt supplemented with vita $\mathrm{E}$ recorded the lowest BW compared with other groups. As well as, BWG had the same trained as BW at 0-3 weeks of age. While, at 3-6 weeks of age BWG increased with salt stress compared with other groups. Moreover, there were no significant differences between control and salt stress at 3-6. Contrary, water intake decreased at 0-3, 3-6 and 0-6 weeks of age compare with other groups. While, birds received salt supplemented with vita $\mathrm{C}$ recorded the highest WI and FI during experimental periods. Birds received vitamins $\mathrm{E}$ or $\mathrm{C}$ recorded the worst FC during the experimental periods. These results are similar to the results obtained by (Watkins et al., 2005). He found that in dietary $\mathrm{NaCl}$ level based on the amount of $\mathrm{Na}$ in the drinking water of combination of $500 \mathrm{mg}$ $\mathrm{Na} / \mathrm{L}$ in the water did not affect the feed intake. Total body weight gain was not affected by the treatment and weekly growth rate also was not affected by the different levels of $\mathrm{NaCl}$ in drinking water during the experimental period, except on week four. These findings were in line with results obtained by (Ross, 1979). The requirement of these 2 ions varied from 0.15 to $0.40 \%$ for $\mathrm{Na}+$ and 0.15 to $0.30 \%$ for $\mathrm{Cl}-$ (NRC, 1994; Oviedo-Rond ø'n et al., 2001; and Murakami et al., 2001). Excessive dietary $\mathrm{Na}+$ causes physiological responses such as increased water consumption, manure moisture and urinary excretion and significantly decreases kidney glomerular filtration ratio, which is regulated by variation in the argininevasotocin secretion (Vena et al., 1990). Therefore, it is necessary to provide the $\mathrm{Na}+$ and $\mathrm{Cl}-$ in proper amounts to ensure minimum secretions through kidney. The variation may be due to the concentrations of mineral salt which significantly impaired performance are considerably higher than the concentrations normally found in drinking water including underground sources. Gene et al. (1999) reported that feed conversion ratio was not affected by the treatment during the experimental period except on week one and two with different dietary sodium levels $(0.1 \%-0.3$ $\%-0.7 \%-0.9 \% \mathrm{NaCl}$ ) show that about $0.4 \%$ added sodium chloride is necessary to achieve maximum fed conversion ratio; and added that, the variation may be due to high level of $\mathrm{NaCl}$ for dietary source and the water source. Water intake significantly differ with our treatments in contrast with Austic (1985) who indicated that weekly water consumption was not affected by the different levels of $\mathrm{NaCl}$ in the experiment except on week two, these findings agree with those result reported by where $\mathrm{NaCl}$ supplements of up to $2 \mathrm{~g} / 1$ of 
drinking water or $4 \mathrm{~g} / \mathrm{kg}$ of diet were given between (one and six weeks of age to broiler) chick receiving commercial diet containing $2.5 \mathrm{~g} \quad \mathrm{NaCl} / \mathrm{Kg}$ observed increase in the intakes of drinking water up to $15 \%$ the variation may be due to environmental conditions of the study or they may include the palatability of the diet or any changes in water supply under hot climatic conditions.

Dressed carcass, relative weights of some organs (gizzard, liver, heart, and spleen) of broiler as affected by treatments:

The results presented in (Table 3 ) indicated the effect of treatments on dressed carcass, abdominal fat and relative weights of some edible organs such as gizzard, liver, heart, and spleen. Salt stress with or without vitamin addition increased ( $p>0.05)$ dressed carcass and abdominal fat compared with control birds. There were no significant differences among all experimental groups in dressed carcass, blood \%, gizzard, liver, spleen $\%$ and ceca length. Abdominal fat \% for birds treated with $3000 \mathrm{mg} / \mathrm{L} \mathrm{NaCl}$ and those of $3000 \mathrm{mg} / \mathrm{L} \mathrm{NaCl}$ plus vita $\mathrm{C}$ were increased significantly $(\mathrm{p}<0.05)$ compared with other experimental groups. Additionally, it was observed that birds received $500 \mathrm{IU} / \mathrm{L}$ of water L-ascorbic acid significantly $(p<0.01)$ decreased length of intestines compared with control group. With regard to the carcass quality there were significant effects among the treatments for various characteristics. The treated groups (T3 and T4) showed insignificantly higher dressing percentage than other groups (Table 3). Borges et al. (2003) noted that the use of electrolytes in drinking water had no significant effect on carcass traits. In the present experiment only the abdominal fat significantly decreased with increasing $\mathrm{NaCl}$ supplementation and $3000 \mathrm{ppm} \mathrm{NaCl}$ plus Vita $\mathrm{E}$ produced the lowest means of all groups except control group. Mushtag (2005) showed high dietary $\mathrm{Na}+(0.3 \%)$ decreased abdominal fat under subtropical summer conditions.

\section{Blood salts and Aldestrol as affected by treatments:}

Data of $\mathrm{K}, \mathrm{Ca}, \mathrm{Mg}, \mathrm{Na}, \mathrm{P}$ and aldestrol throughout the experiment period are shown (Fig. 1 and 2). It was found a significant decrease $(\mathrm{p}<0.01)$ in $\mathrm{K}$ and $\mathrm{Ca}$ of birds fed diets supplemented with Vita $\mathrm{E}$ and $\mathrm{C}$ compared with other groups; while salt stress treatment (T1) decreased $\mathrm{Na}, \mathrm{P}$ and aldestrol concentration compared with control group except for $\mathrm{Na}$ level. Moreover, $\mathrm{Na}$ level increased $(\mathrm{p}<0.05)$ significantly in salt stress groups $\mathrm{T} 3$. Additionally, there were no significant differences among treatments in $\mathrm{Mg}$ concentration. Furthermore, treated groups T1, T2 and T3 showed decline adlestrol concentration compared with control group. Sodium and $\mathrm{Cl}$ are minerals with important physiological functions. Optimum dietary balance of these minerals allows better chicken performance and may reduce leg problems. Sodium is an essential element for animals; the body contains approximately $0.2 \%$ of sodium. About one - quarter of this amount is localized in the skeleton in an insoluble rather inert form, but the balance was found in the extra cellular fluids where it undergoes a very active metabolism. The element makes up $93 \%$ of the bases of the blood serum and thus it was the predominant basic element concerned in neutrality regulation sodium seems to be absent from blood cells, but it does occur in considerable amount in the muscles, where it is associated in some unknown way with their contraction. A lack of the elements also lowers the utilization of digested protein and energy and prevents reproduction.

Chloride is differing from sodium, it is found in large concentrations both within and outside of the cells of the body tissues. Blood cells contain about one-half as much as the plasma, approximately 15 to $20 \%$ of the chlorides of the bloods, principally sodium chloride, make up two-thirds of its acidic ions. This indicates their large role in acid-base regulation. The gastric secretion 
contains chlorines as free acid and in the form of salts. The body has a certain capacity to store chlorine in the skin and subcutaneous tissues. Its excretion follows that of sodium, the body requirement is approximately half of that for sodium. Our results indicated that blood minerals significantly affected with salt stress with or without vitamin addition and these may be due to aldosterone mechanism of action. Aldosterone is a steroid hormone (mineralocorticoid family) produced by the outer section (zona glomerulosa) of the adrenal cortex in the adrenal gland. It plays a central role in the regulation of blood pressure mainly by acting on the distal tubules and collecting ducts of the nephron, increasing reabsorption of ions and water in the kidney, to cause the conservation of sodium, secretion of potassium, increase in water retention, and increase in blood pressure and blood volume. Aldosterone tends to promote $\mathrm{Na}+$ and water retention, and lower plasma $\mathrm{K}+$ concentration by the following mechanisms: Acting on the nuclear mineralocorticoid receptors (MR) within the principal cells of the distal tubule and the collecting duct of the kidney nephron, it upregulates and activates the basolateral $\mathrm{Na}+/ \mathrm{K}+$ pumps, which pumps three sodium ions out of the cell, into the interstitial fluid and two potassium ions into the cell from the interstitial fluid. This creates a concentration gradient which results in reabsorption of sodium $(\mathrm{Na}+)$ ions and water (which follows sodium) into the blood, and secreting potassium $(\mathrm{K}+)$ ions into the urine (lumen of collecting duct) (Changlong et al., 2012). Lawrence and Gustavo (2000) said that Aldosterone has been implicated in the regulation of both $\mathrm{Na}$ and $\mathrm{K}$ concentrations in the plasma. Release of the hormone is known to be stimulated by high plasma $\mathrm{K}$ and infusion of aldosterone lowers plasma $\mathrm{K}$. However, the correlation between changes in mineralocorticoid levels and rates of $\mathrm{K}$ secretion is not perfect, suggesting that other factors may be involved. In conclusion, addition of $100 \mathrm{IU} / \mathrm{kg}$ of feed DL- $\alpha$-tocopherol and/or $500 \mathrm{IU} / \mathrm{L}$ of water L-ascorbic acid during salinity stress partially alleviate the adversely of salinity water. 
Table (1): Composition and calculated analysis of experimental diets

\begin{tabular}{|l|c|c|}
\hline \multicolumn{1}{|c|}{ Ingredients, } & Starter diet & Grower diet \\
\hline Yellow corn & 62.18 & 67.00 \\
Soybean meal (44\% CP) & 27 & 20.30 \\
Corn gluten meal (60\% CP) & 6.3 & 8.00 \\
Veg. Oil & -- & -- \\
Di-Calcium Phosphate & 1.92 & 1.9 \\
Limestone & 1.29 & 1.37 \\
Salt (NaCl) & 0.12 & 0.10 \\
DL-Methionine & 0.14 & 0.24 \\
L-Lysine & 0.19 & 0.48 \\
Vit. \& Min. Premix ${ }^{1}$ & 0.25 & 0.24 \\
Filler (sand) & 0.01 & 0.37 \\
Total & 99.78 & 100.00 \\
\hline Calculated Analysis, \% & & \\
& 3010 & 3160 \\
ME (kcal/ kg) & & \\
Crude Protein & 23 & 21 \\
Calcium & 1.00 & 1.00 \\
Available Phosphorus & 0.50 & 0.50 \\
Lysine & 1.16 & 1.28 \\
Methionine & 0.52 & 0.59 \\
Choline (mg/ kg) & 0.13 & 0.15 \\
\hline
\end{tabular}

${ }^{1}$ Premix provides by kg: Vit A: $5500 \mathrm{IU}$; Vit E: $11 \mathrm{IU}$; Vit D3: $1100 \mathrm{IU}$; riboflavin: $4.4 \mathrm{mg}$; Ca pantothenate: $12 \mathrm{mg}$; nicotinic acid: $44 \mathrm{mg}$; choline chloride: $191 \mathrm{mg}$; vitamin B12: $12.1 \mathrm{ug}$; vitamin B6: 2.2mg; thiamine (as thiamine mononitrate): 2.2 $\mathrm{mg}$; folic acid: $0.55 \mathrm{mg}$ and d- biotin: $0.11 \mathrm{mg}$. Trace mineral ( $\mathrm{mg} / \mathrm{kg}$ diet): $\mathrm{Mn}$ : 60; Zn: 50; Fe: 30; Cu: 5 and Se: 0.3. 
Table (2): Productive performance of broiler chicks as affected by treatments

\begin{tabular}{|c|c|c|c|c|c|c|}
\hline \multirow{2}{*}{ Items } & \multicolumn{4}{|c|}{ Treatments } & \multirow{2}{*}{ SEM } & \multirow{2}{*}{ P. value } \\
\hline & Control & 3000 ppm & $\begin{array}{c}3000 \text { ppm } \\
\text { VE }\end{array}$ & $\begin{array}{l}\text { 3000ppm } \\
\text { VC }\end{array}$ & & \\
\hline \multicolumn{7}{|c|}{$\mathrm{BW}(\mathrm{g})$} \\
\hline $3 \mathrm{WK}$ & $852.00^{\mathrm{a}}$ & $822.00^{c}$ & $856.67^{\mathrm{a}}$ & $839.33^{b}$ & 4.34 & 0.0006 \\
\hline $6 \mathrm{WK}$ & $2432.78^{\mathrm{a}}$ & $2338.33^{b}$ & $2139.72^{c}$ & $2458.89^{\mathrm{a}}$ & 38.52 & 0.0001 \\
\hline \multicolumn{7}{|c|}{ BWG (g daily) } \\
\hline $0-3 \mathrm{WK}$ & $38.42^{\mathrm{ab}}$ & $36.98^{\mathrm{b}}$ & $38.63^{\mathrm{a}}$ & $37.78^{\mathrm{ab}}$ & 0.27 & 0.1073 \\
\hline $3-6 \mathrm{WK}$ & $75.28^{\mathrm{a}}$ & $72.21^{\mathrm{a}}$ & $61.10^{\mathrm{b}}$ & $77.12^{\mathrm{a}}$ & 2.04 & 0.0013 \\
\hline $0-6 \mathrm{WK}$ & $56.85^{\mathrm{a}}$ & $54.60^{\mathrm{b}}$ & $49.87^{\mathrm{c}}$ & $57.45^{\mathrm{a}}$ & 0.93 & 0.0001 \\
\hline \multicolumn{7}{|c|}{ Water Intake /Bird/Day } \\
\hline $0-3 \mathrm{WK}$ & $135.05^{\mathrm{a}}$ & $130.62^{b}$ & $136.16^{\mathrm{a}}$ & $137.38^{\mathrm{a}}$ & 0.845 & 0.0129 \\
\hline $3-6 \mathrm{WK}$ & $289.80^{\mathrm{b}}$ & $283.87^{\mathrm{c}}$ & $291.57^{b}$ & $295.52^{\mathrm{a}}$ & 0.812 & 0.001 \\
\hline $0-6 \mathrm{WK}$ & $264.33^{\mathrm{b}}$ & $238.98^{c}$ & $266.09^{\mathrm{ab}}$ & $269.35^{\mathrm{a}}$ & 1.16 & 0.002 \\
\hline \multicolumn{7}{|c|}{ FI (g daily) } \\
\hline $0-3 \mathrm{WK}$ & $70.24^{\mathrm{a}}$ & $69.29^{\mathrm{a}}$ & $67.78^{\mathrm{b}}$ & $67.59^{\mathrm{b}}$ & 0.37 & 0.0026 \\
\hline $3-6 \mathrm{WK}$ & $158.33^{\mathrm{a}}$ & $156.11^{\mathrm{b}}$ & $149.92^{\mathrm{d}}$ & $152.94^{\mathrm{c}}$ & 0.97 & 0.0001 \\
\hline $0-6 \mathrm{WK}$ & $114.29^{\mathrm{a}}$ & $112.70^{\mathrm{b}}$ & $108.85^{\mathrm{d}}$ & $110.26^{\mathrm{c}}$ & 0.66 & 0.0001 \\
\hline \multicolumn{7}{|c|}{ FCR (g feed / g growth) } \\
\hline $0-3 \mathrm{WK}$ & $1.828^{\mathrm{ab}}$ & $1.874^{\mathrm{a}}$ & $1.755^{\mathrm{b}}$ & $1.790^{\mathrm{b}}$ & 0.017 & 0.0437 \\
\hline $3-6 \mathrm{WK}$ & $2.118^{\mathrm{bc}}$ & $2.173^{\mathrm{b}}$ & $2.499^{\mathrm{a}}$ & $1.987^{\mathrm{c}}$ & 0.060 & 0.0001 \\
\hline $0-6 \mathrm{WK}$ & $2.016^{\mathrm{bc}}$ & $2.068^{\mathrm{b}}$ & $2.198^{\mathrm{a}}$ & $1.920^{\mathrm{c}}$ & 0.034 & 0.0048 \\
\hline
\end{tabular}

$\mathrm{a}, \mathrm{b}, \mathrm{c}$ : Means in the same row having different superscripts are significantly different at $(\mathrm{p}<0.05)$. 
Table (3): Slaughter traits of broiler chicks as affected by treatments

\begin{tabular}{|c|c|c|c|c|c|c|}
\hline & Control & $\begin{array}{l}3000 \\
\text { ppm }\end{array}$ & $\begin{array}{c}3000 \text { ppm } \\
\text { VE }\end{array}$ & $\begin{array}{c}3000 \text { ppm } \\
\text { VC }\end{array}$ & SEM & P. value \\
\hline $\begin{array}{l}\text { Dressed carcass } \\
\text { (including giblets) (\%) }\end{array}$ & 79.47 & 79.44 & 81.46 & 80.08 & 0.35 & 0.1227 \\
\hline Abdominal fat $(\%)$ & $0.76^{\mathrm{b}}$ & $1.34^{\mathrm{a}}$ & $0.83^{b}$ & $1.22^{\mathrm{a}}$ & 0.08 & 0.0001 \\
\hline $\begin{array}{l}\text { Blood }(\%) \\
\text { Body organ weights } \\
(\%)\end{array}$ & 4.18 & 4.11 & 4.27 & 3.87 & 0.08 & 0.4072 \\
\hline Gizzard & 1.38 & 1.60 & 1.50 & 1.45 & 0.04 & 0.3045 \\
\hline Liver & 2.75 & 2.40 & 2.60 & 2.51 & 0.07 & 0.3949 \\
\hline Heart & $0.61^{\mathrm{c}}$ & $0.76^{\mathrm{a}}$ & $0.67^{b}$ & $0.55^{\mathrm{d}}$ & 0.02 & 0.0001 \\
\hline Spleen & 0.19 & 0.24 & 0.23 & 0.24 & 0.01 & 0.0523 \\
\hline $\begin{array}{l}\text { Body organs length } \\
(\mathrm{cm})\end{array}$ & & & & & & \\
\hline Intestines & $227.67^{\mathrm{a}}$ & $203.33^{b}$ & $201.67^{\mathrm{b}}$ & $202.00^{\mathrm{b}}$ & 3.38 & 0.0001 \\
\hline Ceca & 40.33 & 38.00 & 38.67 & 38.33 & 0.32 & 0.0158 \\
\hline
\end{tabular}

$a, b, c, d$ : Means in the same row having different superscripts are significantly different at $(\mathrm{p}<0.05)$. 

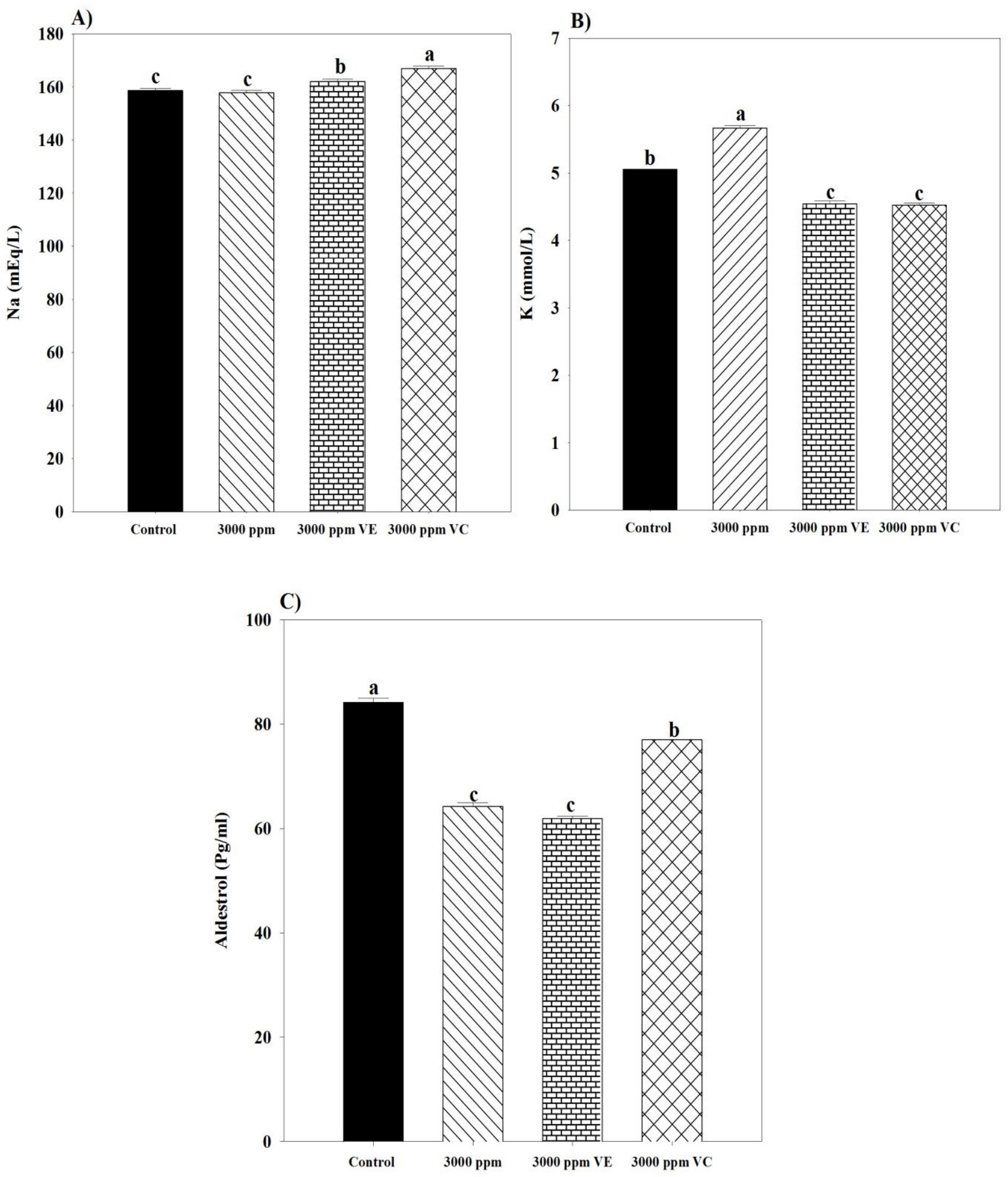

Fig. (1): Blood Na, K and Aldosterone levels as affected by treatments

Fig. (2): Blood Ca, P and Mg levels as affected by treatments 


\section{REFERENCES}

Afifi, M.; Maie, F. A.; and AbdelMaksoud, A. M., 1992. Salt stress in broiler chicks: 1. Report: effect of salt stress on some productive traits in broiler chicks. Arch. Geflÿgelk. 56: 124128.

Austic, R. E., 1985. Development and adaptation of protein digestion. J. Nutri., : 686 -697.

Borges, S. A.; Fischer, A. V. Da Silva; Ariki, J.; Hooge, D. M.; and Cummings, K. R., 2003. Dietary electrolyte balance for broiler chickens under moderate high ambient temperature and relative humidity.

Poult. Sci., 82: 301-308.

Changlong Hu; Craig, Rusin, G.; Zhiyong, Tan; Nick, A. Guagliardo; and Paula, Q. Barrett, 2012. Zona glomerulosa cells of the mouse adrenal cortex are intrinsic electrical oscillators. J. Clinic., 122: 2046-2053.

Damron, B. L., 1998. Sodium chloride concentration in drinking water and eggshell quality. Poult. Sci., 77: 14881491.

Duncan, D. B., 1955. Multiple Range and Multiple (F-test). Biometrics, 11: 1-42.

Franchini, A.; Canti, M.; Manfreda, G.; Bertuzzi, S.; As-drubali, G.; and Franciosi, C., 1991. Vitamin E as adjuvant in emulsified vaccine for chicks. Poult. Sci., 70(8): 1709-1715.

Gene. M. Pesti; Hector, Cervantes; Remzii, Bakalli; Bafundo, K. W.; and Garcia, M. N., 1999. Department of poiultry science university of Georgia, Athens, Georgia. Poult. Sci., 78: 15521560.

Khalafalla, M. K.; Bessei, W.; and Schwarzenberg, A., 1998. Effect of mineral salts in drinking water on the domestic chicken performance $Đ$ a literature review. Archiv. Geflÿgelk; 62: 6-32.

Lawrence, G. Palmer; and Gustavo, Frindt, 2000. Aldosterone and potassium secretion by the cortical collecting duct. Kidney Int., 57: 1324 1328.

Lesson, S.; and Summers, J. D., 1997. Ingredient evaluation and diet formulation, In Commercial Poultry Nutrition $2^{\text {nd }}$ Ed, pp: 101-109.

Meydani, S. N.; and Blumberg, J. B., 1993. Vitamin $E$ and the immune response, In: Cunningham-Rundles, S., Ed., Nutrient Modulation of the Immune Response, Marcel Dekker, New York, pp: 223-238.

Murakami, A. E.; Rondø'n, E. O. O.; Martins, E. N.; Pereira, M. S.; and Scapinello, C., 2001. Sodium and chloride requirements of growing broiler chickens (twenty-one to forty-two days of age) fed corn-soybean diets. Poult. Sci. 80: 289-294.

Mushtag, T.; Sarwar, M.; Mirza, H.; Aslam, M.; and Ahmad, T., 2005. Effect and interactions of dietary sodium and chloride on broiler starter performance (hatching to twenty-eight days of age) under subtropical summer conditions. Poult. Sci., 84: 1716-1722.

NRC, National Research Council, 1994.

Nutrient requirements of poultry. 8.rev.ed. Washington, DC. National Academy Press, p: 155.

Oviedo-Rondø’n, E. O. O.; Murakami, A. E.; Furlan, A. C.; Moreira, I.; and Macari, M., 2001. Sodium and chloride requirements of growing broiler chickens fed corn-soybean diets (one to twenty-one days of age). Poult. Sci., 80: 592-598.

Ross, E., 1979. The Effect of Water Sodium on the Chic Requirement for Dietary Sodium. Poult. Sci., 58: 625630.

Smith, M. O., 1994. Effect of electrolytes and lighting regimen on growth of heat distressed broilers. Poult. Sci., 73: 350353.

Soares, L. F.; Ribeiro, A. M. L.; and Penz Jr., A. M., 2007. Influência da restrição hídrica, durante a fase pré- 
inicial, no desempenho de frangos de corte (Influence of water restriction during the pre-initial phase, the performance of broiler chickens). Revista Brasileira de Zootecnia, 5: 1579-1589.

Vena, V. E.; Lac, T. H.; and Wideman, R. F., 1990. Dietary sodium, glomerular filtration rate. Autorregulation and glomerular size distribution profiles in domestic fowl (Gallus gallus). J. Comp. Physiol., 160: 7-16.

Viola, T. H.; Ribeiro, A. M. L.; and Penz JR., A. M., 2009. The Influence of Water Restriction on the Performance and Organ Development of Young Broilers. Revista Brasileira de Zootecnia, 38: 323-327.

Watkins, S. E.; Firtts, C. A.; Yan, F.; Wilson, M. C.; and World group, P. W., 2005. Interaction of sodium chloride levels in poultry drinking water and the diet of broilers chickens. J. Appl. Poult. Res., 14: 55-59.

Zimmermann, N. G.; Dhillon, A. S.; Barton, T. L.; and Andrews, L. D., 1993. Relationship of drinking water quality and broiler performance in Washington State. Poult. Sci., 72:

\footnotetext{
الملخص العربى

تأثير الفيتامينات علي الأداء الإنتاجي والفسيولوجي لاجاج التسمين تحت الإجهاد الملحي

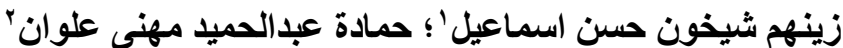

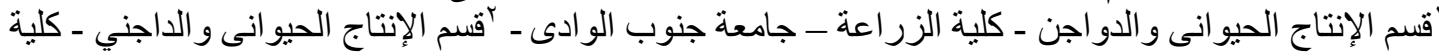
الزر اعة - جامعة المنيا

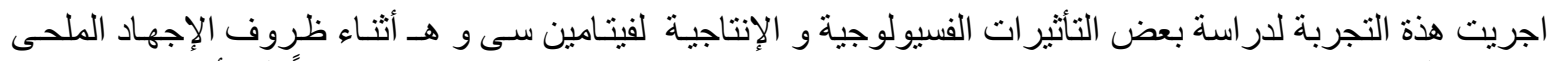

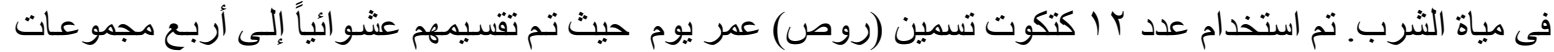

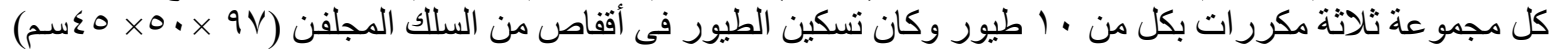

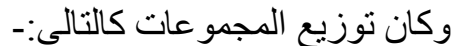

ا • المعاملة الأولى تم إمداد الطيور بمياه الثرب (ماء الصنبور ) بدون أى إضافات واستخدمت ككنترول.

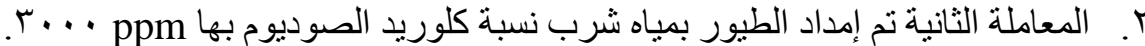

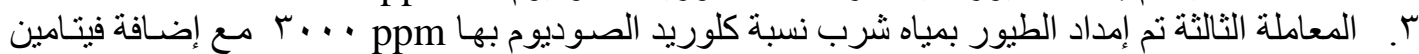

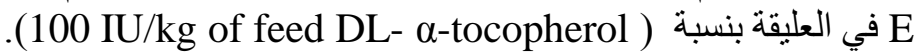

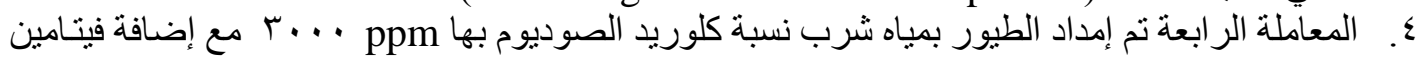

C في العليقة بنسبة (500 IU/L of water L-ascorbic acid).

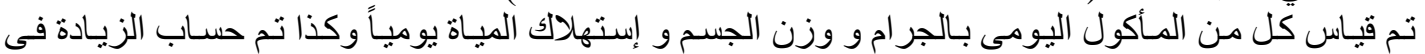

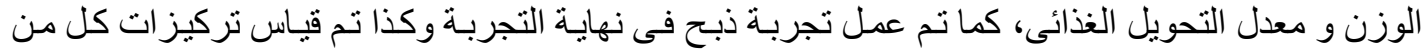

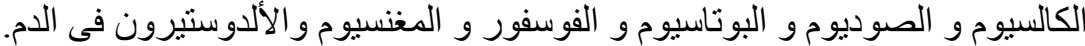

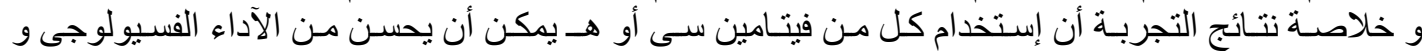

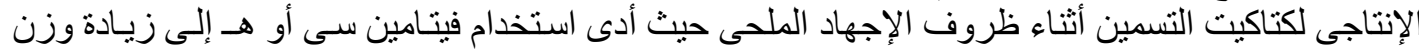

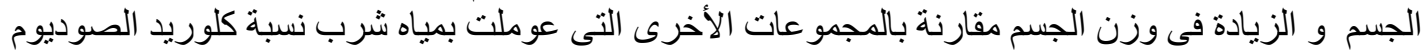

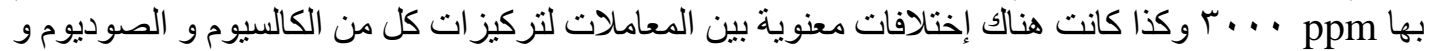

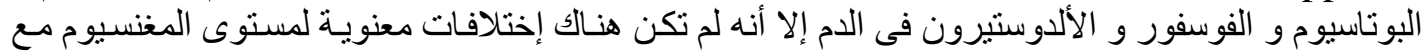
إختلاف المعاملات ونستنتج من هذة الدراس اسـة أن استخدام فيتامين سـى أو هـ أثناء ظروف الإجهاد الملحى قد يحسن من الحالة الفسيولوجية و الإنتاجية للطائر.
} 